\title{
PREFERENSI WISATAWAN BERPASANGAN MANCANEGARA TERHADAP PRODUK WISATA DI GILI TRAWANGAN, LOMBOK UTARA, NUSA TENGGARA BARAT
}

\author{
Zyendira Amanda Zanuar \\ I Made Sendra \\ I GPB Sasrawan Mananda \\ Email: zyendira.amanda@gmail.com \\ PS. S1 Industri Perjalanan Wisata \\ Fakultas Pariwisata UNUD
}

\begin{abstract}
This study discusses on couple tourist preferences of the tourism product in Gili Trawangan, including it's characteristics. Preferences is a choice on alternatives based on their relatives utility, a process which results in an optimal choice (whether real or theoretical). The aim of this study is to determine how couple tourist preference of the tourism product in Gili Trawangan. Methods of data collection utilized observation, questionnaire, literature study, and documentation. The result show that the characteristic of the couple tourist in Gili Trawangan are divided into tourist descriptor and trip-descriptor. The characteristic of tourist descriptor is dominated by couple tourists from Europe, whose age are 25-44 years with the single status and the young couple. Moreover, the characteristic of a trip-descriptor is dominated by couple tourists. The purpose of their traveling to Gili Trawangan is the holiday. Most of them received information from the internet who arranged their own travel and they traveled during the holiday season with the length of stay is 2-3 days in Gili Trawangan. As for couple tourist preferences to Gili Trawangan divided into 4 preferences, i.e the preference based on transportation, accommodation, the place to have a meal, and tourist activity. In term of transportation the couple tourist preferred bicycle and in term of accommodation they preferred homestay. Concerning the place having a meal they preferred to a restaurant and for as tourism activity they preferred snorkeling.
\end{abstract}

\section{Keywords: Preference, Couple Tourist, Product Tourism, Characteristic.}

\section{PENDAHULUAN}

Pariwisata merupakan suatu perjalanan yang dilakukan seseorang sementara waktu, dilakukan dari suatu tempat ke tempat lain, perjalanan tersebut dikaitkan dengan pertamasyaan atau rekreasi dan perjalanan tersebut bukan dengan maksud untuk mencari nafkah.

Dewasa ini, kegiatan berwisata bukan hanya sekedar untuk refreshing namun saat ini sudah menjadi sebuah kebutuhan manusia dan gaya hidup seseorang. Trend gaya hidup berwisata ini semakin marak dengan adanya informasi dari social media, reality show di televisi, dan artikelartikel yang memuat tentang keberagaman pariwisata di Indonesia.

Sejak didatangi wisatawan pada 1986, industri pariwisata di Tiga Gili (Gili Trawangan, Gili Meno, Gili Air) berkembang pesat. Wisatawan yang datang hampir $98 \%$ wisatawan mancanegara. Hal ini menyebabkan meningkatnya produk pariwisata bagi wisatawan. Produk wisata 
dapat merupakan susunan produk terpadu, yang terdiri dari daya tarik wisata, transportasi, akomodasi dan hiburan, dimana setiap unsurnya disiapkan oleh masing-masing perusahaan dan ditawarkan terpisah kepada wisatawan (Burkat dan Medlik, dalam Yoeti 1996:164).

Gili Trawangan memiliki fasilitas produk wisata yang lebih unggul dibanding Gili Meno dan Gili Air. Gili Trawangan memiliki berbagai jenis fasilitas akomodasi mulai dari hotel berbintang, villa, sampai homestay, fasilitas restoran dan bar yang beragam menyajikan menu seperti seafood, dan fasilitas penunjang pariwisata seperti money changer, ATM, dan minimarket. Gili Trawangan menjadi daya tarik wisata kelas dunia, yang meraih penghargaan "Travellers Choice Island Award 2014" sebagai tujuan pulau wisata terbaik keempat dari 100 pulau di dunia yang diberikan situs perjalanan wisata dunia TripAdvisor.com. Penghargaan tersebut dinilai berdasarkan kualitas dan kuantitas hotel, restoran, serta jumlah objek wisata di tiap pulau. TripAdvisor pun mengumpulkan masing-masing data dalam jangka waktu 12 bulan (travel.detik.com, diakses 9 Maret 2016).

Semakin berkembangnya suatu destinasi, permintaan wisatawan pun semakin beragam. Wisatawan pun memiliki selera yang berbeda-beda yang mengakibatkan berbeda pula produk wisata yang diinginkan dan disukai wisatawan di setiap destinasi. Sikap suka terhadap suatu hal merupakan sebuah pilihan. Suatu sikap konsumen terhadap satu pilihan produk yang terbentuk melalui evaluasi atas berbagai macam merek dalam berbagai pilihan yang tersedia disebut preferensi konsumen (Kotler, 2009: 181).

Preferensi wisatawan dipilih peneliti sebagai subjek penelitian untuk mengukur seberapa besar minat kesukaan wisatawan terhadap suatu produk wisata yang ditawarkan di suatu destinasi dan sangat berhubungan dengan keputusan wisatawan melakukan perjalanan. Dalam hal ini produk wisata yang menjadi tolak ukur preferensi adalah transportasi, akomodasi, tempat makan dan minum, dan aktivitas wisata.

Berdasarkan hal tersebut, realitas perjalanan wisatawan menarik untuk dibahas. Perjalanan wisatawan ke suatu destinasi pariwisata dan preferensi produk wisata bagi wisatawan tidak selalu sama karena dipengaruhi situasi dan kondisi. Kajian sosiologi pariwisata ini sangat penting. Hal tersebut dapat menjadi bahan evaluasi bagi para pengelola destinasi dan pelaku pariwisata di Gili Trawangan.

\section{METODE}

Lokasi dilakukan di Gili Trawangan, Desa Gili Indah, Kecamatan Pemenang, Kabupaten Lombok Utara, Nusa Tenggara Barat. Gili Trawangan terletak di sebelah Barat Laut Lombok. Pemilihan lokasi ini berfokus pada objek wisata dimana banyak terdapat aktivitas wisatawan seperti seperti pantai, restoran, kafe, dan toko cinderamata.

Terdapat 2 variabel yaitu karakteristik wisatawan dan preferensi wisatawan. Adapun indikator dalam variabel karakteristik dibagi 2, yaitu karakteristik menurut tourist descriptor seperti jenis kelamin, asal wisatawan, umur, pekerjaan, status perkawinan, tipe pasangan, sedangkan karakteristik menurut trip descriptor seperti tujuan perjalanan, informasi perjalanan, pengorganisasian perjalanan, lama waktu perjalanan, waktu melakukan perjalanan, periodisitas perjalanan, dan kesediaan kembali. Preferensi wisatawan menggunakan 4 indikator dengan pengukuran produk wisata, yaitu jasa transportasi, jasa akomodasi, jasa makanan dan minuman, jasa wisata.

Pengumpulan data menggunakan observasi, kuesioner, wawancara, studi kepustakaan, dan dokumentasi. Teknik penentuan sampel menggunakan purposive sampling. Wisatawan sebagai responden adalah wisatawan berpasangan yang 
datang ke Gili Trawangan dengan jumlah 100 responden. Teknik analisis data yang digunakan adalah analisis deskriptif kuantitatif dan analisis tabulasi silang dengan chi-square menggunakan software SPSS. Analisis tabulasi silang dilakukan dengan mentabulasisilangkan variabel preferensi wisatawan dengan karakteristik wisatawan. Hasil dari tabulasi silang tersebut diharapkan dapat memberikan karakteristik yang spesifik mengenai preferensi wisatawan berpasangan terhadap produk wisata di Gili Trawangan.

\section{HASIL}

Hasil kuesioner menunjukkan wisatawan berpasangan yang berkunjung ke Gili Trawangan memiliki karakteristik yang beragam. Analisis karakteristik berdasarkan tourist descriptor yaitu karakteristik wisatawan dari keragaman jenis wisatawan yang terdiri atas jenis kelamin, asal wisatawan, umur, pekerjaan, status perkawinan, dan tipe pasangan.

Tabel 1 Karakteristik menurut Tourist Desciptor

\begin{tabular}{|c|c|c|c|}
\hline No & & Identitas Responden & Persentase \\
\hline \multirow[t]{2}{*}{1} & \multirow[t]{2}{*}{ Jenis Kelamin } & Laki-laki & $42 \%$ \\
\hline & & Perempuan & $58 \%$ \\
\hline \multirow{5}{*}{2} & \multirow{5}{*}{ Asal wisatawan } & Eropa & $34 \%$ \\
\hline & & Amerika & $21 \%$ \\
\hline & & Afrika & $6 \%$ \\
\hline & & Asia & $18 \%$ \\
\hline & & Australia & $21 \%$ \\
\hline \multirow{5}{*}{3} & \multirow{5}{*}{ Umur } & $<14$ tahun & $0 \%$ \\
\hline & & 15-24 tahun & $44 \%$ \\
\hline & & $25-44$ tahun & $50 \%$ \\
\hline & & 45-65 tahun & $5 \%$ \\
\hline & & $>65$ tahun & $1 \%$ \\
\hline \multirow{8}{*}{4} & \multirow{8}{*}{ Pekerjaan } & Pelajar/Mahasiswa & $26 \%$ \\
\hline & & Pengusaha & $11 \%$ \\
\hline & & Pekerja Seni & $6 \%$ \\
\hline & & Pegawai Negeri & $4 \%$ \\
\hline & & Karyawan & $19 \%$ \\
\hline & & Ibu Rumah Tangga & $7 \%$ \\
\hline & & Ahli & $3 \%$ \\
\hline & & Lainnya & $19 \%$ \\
\hline \multirow[t]{2}{*}{5} & \multirow{2}{*}{$\begin{array}{l}\text { Status } \\
\text { perkawinan }\end{array}$} & Menikah & $31 \%$ \\
\hline & & Belum menikah & $69 \%$ \\
\hline \multirow{4}{*}{6} & \multirow{4}{*}{$\begin{array}{l}\text { Type of Travel } \\
\text { Partner }\end{array}$} & Pasangan muda & $69 \%$ \\
\hline & & Honeymooners & $11 \%$ \\
\hline & & Pasangan yang sudah menikah dan memiliki anak & $15 \%$ \\
\hline & & Pasangan tua & $5 \%$ \\
\hline
\end{tabular}

Sumber: Hasil Penelitian, 2016.

Wisatawan berpasangan yang mengisi kuesioner di Gili Trawangan terdiri dari $42 \%$ wisatawan laki-laki dan $58 \%$ wisatawan perempuan. Meskipun hasil survey mendapatkan wisatawan dengan jenis kelamin perempuan lebih banyak namun hal itu tidak terlalu signifikan dengan asal wisatawan dari berbagai benua di dunia. Wisatawan berpasangan dari benua Eropa mendominasi sebanyak 34\%.

Kelompok usia wisatawan berpasangan pada kelompok 25-44 tahun lebih banyak dibandingkan dengan kelompok usia lainnya. Seperempat dari total wisatawan 
berpasangan ke Gili Trawangan adalah mahasiswa/pelajar, yang juga dapat dilihat dari status perkawinan lebih banyak wisatawan berpasangan yang belum menikah dengan persentase sebesar $69 \%$.

Tipe pasangan terbagi menjadi 4 yaitu young couple atau pasangan muda, honeymooners, couple with children yaitu wisatawan berpasangan yang sudah menikah dan mempunyai anak, dan elderly couple atau wisatawan berpasangan lanjut usia. Wisatawan berpasangan muda atau yang belum berstatus menikah mendominasi yaitu $69 \%$.

Tabel 2 Karakteristik menurut Trip Desciptor

\begin{tabular}{|c|c|c|c|}
\hline No & & tas Responden & Persentase \\
\hline \multirow{7}{*}{1} & \multirow{7}{*}{ Tujuan datang } & Liburan & $88 \%$ \\
\hline & & Penelitian/studi & $5 \%$ \\
\hline & & Mengunjungi kerabat/keluarga & \\
\hline & & & $2 \%$ \\
\hline & & Bisnis & $3 \%$ \\
\hline & & Olahraga & $0 \%$ \\
\hline & & Lainnya & $2 \%$ \\
\hline \multirow{7}{*}{2} & \multirow{7}{*}{ Informasi Perjalanan } & Kerabat/keluarga & $17 \%$ \\
\hline & & Internet & $42 \%$ \\
\hline & & Travel agent & $21 \%$ \\
\hline & & Brosur/buku/majalah & $5 \%$ \\
\hline & & Radio/televise & $0 \%$ \\
\hline & & Tourist Information Centre (TIC) & \\
\hline & & & $15 \%$ \\
\hline \multirow[t]{2}{*}{3} & \multirow[t]{2}{*}{ Pengorganisasian perjalanan } & Sendiri & $71 \%$ \\
\hline & & Paket tour & $29 \%$ \\
\hline \multirow{5}{*}{4} & \multirow{5}{*}{ Lama tinggal } & 1 hari & $0 \%$ \\
\hline & & 2-3 hari & $52 \%$ \\
\hline & & 4-7 hari & $43 \%$ \\
\hline & & $8-28$ hari & $5 \%$ \\
\hline & & $>29$ hari & $0 \%$ \\
\hline \multirow[t]{3}{*}{5} & \multirow[t]{3}{*}{ Waktu pelaksanaan perjalanan } & Hari kerja & $42 \%$ \\
\hline & & Akhir pecan & $15 \%$ \\
\hline & & Hari libur & $43 \%$ \\
\hline \multirow{4}{*}{6} & \multirow{4}{*}{ Periodisitas kunjungan } & Pertama kali & $84 \%$ \\
\hline & & $2-5 \mathrm{kali}$ & $13 \%$ \\
\hline & & $>5$ kali & $3 \%$ \\
\hline & & Rutin & $0 \%$ \\
\hline \multirow[t]{2}{*}{7} & \multirow[t]{2}{*}{ Kembali berkunjung } & $\mathrm{Ya}$ & $96 \%$ \\
\hline & & Tidak & $4 \%$ \\
\hline
\end{tabular}

Sumber: Hasil Penelitian, 2016.

Analisis karakteristik berdasarkan trip descriptor atau karakteristik perjalanannya, yaitu tujuan perjalanan, informasi perjalanan, pengorganisaisan perjalanan, lama waktu perjalanan, waktu melakukan perjalanan, periodisitas perjalanan, dan kesediaan kembali.

Keindahan serta keromantisan Gili Trawangan merupakan alasan banyaknya wisatawan berpasangan datang berkunjung untuk liburan ditengah kesibukan seharihari. Pada Tabel 2, dibuktikan dengan dominannya wisatawan berpasangan berkunjung ke Gili Trawangan untuk liburan sebanyak $88 \%$. Informasi mengenai Gili Trawangan paling banyak didapat melalui internet sebesar $42 \%$. Selain dari internet, informasi mengenai tempat wisata ini juga didapat dari travel agent, kerabat/keluarga, Tourist 
Information Center (TIC), dan juga dari brosur/majalah/buku/leaflet dan sejenisnya. Namun, kurangnya promosi tentang informasi Gili Trawangan di televisi dan radio.

Wisatawan berpasangan yang datang ke Gili Trawangan hampir seluruhnya mengorganisasikan perjalanan wisata secara sendiri yaitu sebesar $71 \%$ dari total responden. Lebih dari setengah total responden mengunjungi Gili Trawangan selama 2-3 hari yaitu sebesar 52\%. Kemudian 43\% wisatawan menghabiskan waktu di Gili Trawangan selama 4-7 hari.
Sebagian wisatawan berpasangan yaitu sebesar $43 \%$ datang pada hari libur, sebesar $42 \%$ datang pada hari kerja, dan paling sedikit $15 \%$ wisatawan datang pada saat akhir pekan. Hampir seluruh wisatawan berpasangan yaitu sebanyak 84\% merupakan kunjungan pertama kali ke Gili Trawangan.

Hampir seluruh wisatawan berpasangan sebanyak $96 \%$ menyatakan kesediannya untuk kembali ke Gili Trawangan.

\section{Tabel 3 Preferensi terhadap Produk Wisata}

\begin{tabular}{|c|c|c|c|}
\hline No & & Identitas Responden & Persentase \\
\hline \multirow[t]{3}{*}{1} & \multirow{3}{*}{$\begin{array}{l}\text { Preferensi moda } \\
\text { transportasi }\end{array}$} & Cidomo & $10 \%$ \\
\hline & & Sepeda & $53 \%$ \\
\hline & & Jalan kaki & $37 \%$ \\
\hline \multirow{8}{*}{2} & \multirow{8}{*}{ Preferensi akomodasi } & Homestay & $31 \%$ \\
\hline & & Hostel/budget hotel & \\
\hline & & & $18 \%$ \\
\hline & & Hotel berbintang & $16 \%$ \\
\hline & & Villa & $26 \%$ \\
\hline & & Rumah kerabat/teman & \\
\hline & & & $2 \%$ \\
\hline & & Lainnya & $7 \%$ \\
\hline \multirow{4}{*}{3} & \multirow{4}{*}{$\begin{array}{l}\text { Preferensi jenis tempat } \\
\text { makan dan minum }\end{array}$} & Restoran & $36 \%$ \\
\hline & & Café & $24 \%$ \\
\hline & & Night Market & $26 \%$ \\
\hline & & Lainnya & $14 \%$ \\
\hline \multirow{4}{*}{4} & \multirow{4}{*}{ Preferensi aktivitas } & Snorkeling & $60 \%$ \\
\hline & & Diving & $15 \%$ \\
\hline & & Watersport & $16 \%$ \\
\hline & & Lainnya & $9 \%$ \\
\hline
\end{tabular}

Sumber: Hasil Penelitian, 2016.

Jenis atau bentuk produk wisata yang dibutuhkan secara langsung oleh wisatawan terdiri dari berbagai jasa pelayanan. Penulis mengambil 4 komponen produk wisata yang paling dibutuhkan wisatawan, yaitu jasa transportasi, jasa akomodasi, jasa makanan dan minuman, dan jasa daya tarik wisata atau aktivitas yang dilakukan di Gili Trawangan.
Preferensi adalah hal yang paling disukai atau hal yang lebih dipilih wisatawan diantara pengelompokan produk wisata. Dari 100 pasangan wisatawan di Gili Trawangan, preferensi wisatawan berpasangan mancanegara di Gili Trawangan adalah sebagai berikut ini.

Preferensi moda transportasi yang wisatawan gunakan di Gili Trawangan lebih banyak menggunakan sepeda yaitu $53 \%$. Akomodasi yang paling disukai 
wisatawan berpasangan adalah homestay, yaitu sebanyak $31 \%$.

Hampir setengah wisatawan berpasangan, yaitu sebesar 36\% memilih restoran sebagai preferensi tempat makan dan minum. Lebih dari setengah wisatawan yaitu sebanyak $60 \%$ memilih aktivitas snorkeling. Selain itu juga memiliki watersport seperti canoe, banana boat, parasailing, dan jetsky. Sebanyak $15 \%$ wisatawan memilih diving sebagai aktivitas yang lebih disukai. Kemudian 9\% wisatawan memilih aktivitas lainnya, seperti beach horsing, berjemur, melihat perkembangan ternak penyu, cooking class dan lain-lain.

\section{PEMBAHASAN}

\section{Karakteristik Wisatawan Berpasangan}

Meskipun hasil survey mendapatkan wisatawan dengan jenis kelamin perempuan lebih banyak namun hal itu tidak terlalu signifikan dengan asal wisatawan dari berbagai benua di dunia. Setiap tahunnya wisatawan berpasangan dari benua Eropa lebih banyak dari wisatawan asal benua lainnya. Kelompok usia wisatawan berpasangan pada kelompok 25-44 tahun lebih banyak dibandingkan dengan kelompok usia lainnya karena kelompok usia ini diperkirakan usia matang yang sudah memiliki pekerjaan dan pendapatan yang tetap. Kemudian kelompok usia 15-24 tahun lebih banyak dikarenakan pada kelompok usia tersebut dapat diasumsikan orang lebih suka mencari pengalaman yang baru dengan mendatangi tempat yang menarik bersama pasangan yang saat ini sedang menjadi trend traveling.

Dilihat dari status perkawinan, Gili Trawangan lebih banyak didatangi oleh wisatawan berpasangan yang belum menikah yang masuk dalam kategori wisatawan berpasangan muda. Tipe pasangan wisatawan lanjut usia paling sedikit dikarenakan wisatawan lanjut usia biasanya lebih memilih pulau yang sepi, dan hanya melakukan aktivitas wisata yang terdapat di akomodasi, sedangkan
Gili Trawangan cukup ramai dan kurang cocok untuk wisatawan lanjut usia.

Keindahan serta keromantisan Gili Trawangan merupakan alasan banyaknya wisatawan berpasangan datang berkunjung untuk liburan ditengah kesibukan seharihari. Informasi mengenai Gili Trawangan paling banyak didapat melalui internet dikarenakan semakin canggih perkembangan teknologi dan banyaknya informasi wisata di sosial media memudahkan wisatawan mendapatkan informasi ke Gili Trawangan. Selain dari internet, informasi mengenai tempat wisata ini juga didapat dari travel agent, kerabat/keluarga, Tourist Information Center (TIC), dan juga dari brosur/majalah/buku/leaflet dan sejenisnya. Namun, kurangnya promosi tentang informasi Gili Trawangan di televisi dan radio.

Wisatawan berpasangan yang datang ke Gili Trawangan lebih menyukai mengorganisasikan perjalanan wisata secara sendiri, karena wisatawan lebih memilih untuk melakukan perjalanan wisata secara bebas dan tidak diatur. Wisatawan berpasangan yang mengunjungi Gili Trawangan rata-rata menghabiskan waktunya selama 2-3 hari dan 4-7 hari, waktu tersebut masih terbilang ideal dalam melakukan perjalanan wisata.

Wisatawan berpasangan lebih suka datang pada hari libur, dan rata-rata wisatawan berpasangan yang datang ke Gili Trawangan merupakan wisatawan first timer. Wisatawan berpasangan bersedia untuk datang kembali karena menurut mereka Gili Trawangan merupakan destinasi wisata yang cukup menarik untuk dikunjungi di Indonesia, sehingga wisatawan akan datang lagi untuk berkunjung.

\section{Preferensi Wisatawan Berpasangan terhadap Produk Wisata}

Preferensi adalah hal yang paling disukai atau hal yang lebih dipilih wisatawan diantara pengelompokan 
produk wisata. Gili Trawangan merupakan pulau kecil yang tidak berpolusi karena moda transportasi yang terdapat disana hanya cidomo dan sepeda, serta dengan berjalan kaki. Wisatawan berpasangan di Gili Trawangan lebih suka menggunakan transportasi sepeda karena harga penyewaan sepeda di Gili Trawangan terbilang murah dibanding menggunakan cidomo, yaitu penyewaan sepeda sebesar Rp 50.000,- hingga Rp 60.000,- perhari untuk satu orang.

Lima akomodasi di Gili Trawangan yang paling unggul, yaitu homestay, hostel/budget hotel, hotel berbintang, villa, rumah kerabat/keluarga, dan penginapan lainnya. Wisatawan memiliki preferensi akomodasi yang berbeda terhadap pilihan akomodasi yang ada. Pertimbangan wisatawan saat memilih akomodasi antara lain biaya menginap, keamanan, fasilitas, serta lokasi dan akses. Banyaknya jumlah homestay di Gili Trawangan membuat wisatawan lebih memilih akomodasi homestay, hal ini dikarenakan populasi homestay lebih banyak dibandingkan akomodasi lainnya.

Jasa makanan dan minuman dibagi pada tiga kelompok, yaitu restoran, café, night market, dan lainnya. Wisatawan memiliki preferensi yang berbeda terhadap pilihan tempat makan mereka dalam perjalanan wisata. Pertimbangan saat memilih tempat makan mencakup harga makanan, kenyamanan, pelayanan, dan juga kualitas makanan. Wisatawan berpasangan Gili Trawangan paling menyukai tempat makan seperti restoran, selain itu juga menyukai night market karena harganya yang terjangkau dan banyaknya pilihan dan jenis makanan yang disediakan di night market, seperti berbagai macam seafood, nasi campur, lalapan, martabak, terang bulan, aneka jus, dan lain-lain.

Wisatawan berpasangan paling suka dengan aktivitas snorkeling. Hal tersebut dikarenakan alam bawah laut Gili Trawangan yang indah sangat dicari wisatawan. Selanjutnya juga wisatawan memilih aktivitas watersport seperti canoe, banana boat, parasailing, dan jetsky. Banyaknya diving class di Gili Trawangan juga membuat wisatawan ingin lebih mengenal bawah laut Gili Trawangan.

\section{SIMPULAN DAN SARAN Simpulan}

Karakteristik wisatawan berpasangan di Gili Trawangan, Lombok Utara, Nusa Tenggara Barat dapat dilihat secara tourist description atau gambaran mengenai diri wisatawan, diketahui bahwa wisatawan berpasangan yang mendominasi adalah pasangan wisatawan asal benua Eropa, berusia 25-44 tahun, dengan status belum menikah dan pasangan muda atau young couple, sedangkan dilihat secara trip description atau gambaran mengenai perjalanannya, yaitu bahwa tujuan mereka datang ke Gili Trawangan untuk liburan. Mereka mendapat informasi dari internet dengan mengatur perjalanannya sendiri pada saat musim liburan dengan lama tinggal di Gili Trawangan selama 2-3 hari dan merupakan kunjungan pertama kali.

Adapun preferensi produk wisata wisatawan berpasangan di Gili Trawangan diklasifikasi menjadi empat preferensi, yaitu preferensi terhadap transportasi, akomodasi, tempat makanan dan minuman, serta aktivitas wisatawan berpasangan. Preferensi wisatawan berpasangan mayoritas menggunakan transportasi sepeda, akomodasi homestay, jenis tempat makan dan minum restoran, dan aktivitas wisata snorkeling.

\section{Saran}

1. Para pengusaha wisata sebaiknya meningkatkan pemasaran Gili Trawangan dengan mempertimbangkan karakteristik wisatawan yang berkunjung, serta produk wisata yang diminati wisatawan berpasangan. Selain itu juga lebih memeperbanyak promosi melalui radio dan televisi. 
2. Pemerintah memberikan perhatian untuk turut ikut serta dalam membantu proses pengembangan fasilitas penunjang produk wisata di Gili Trawangan, seperti fasilitas ATM dan money changer.

\section{DAFTAR PUSTAKA}

Dwiputra, Roby. 2013. Preferensi Wisatawan terhadap Sarana Wisata di Kawasan Wisata Alam Erupsi Merapi.
Kotler, Philip. 2009. Manajemen Pemasaran Edisi 13 Jilid 1. Jakarta: Pearson Education.

Rahmawati, Rieska. 2010. Analisis Preferensi Pengunjung terhadap Paket Wisata Kusuma Agrowisata Kota Batu, Jawa Timur. Bogor: Institut Pertanian Bogor.

Yoeti, Oka A. 1996. Pengantar Ilmu Pariwisata Edisi Revisi. Bandung: Angkasa. 